\title{
Clitoria ternatea L. A Miraculous Plant
}

\author{
Archna Karel $^{1^{*}}$, Hanwant Kumar ${ }^{2}$ and Bhaswati Chowdhary ${ }^{3}$ \\ ${ }^{1}$ Department of (Home Sc.) Foods \& Nutrition, ${ }^{2}$ Department of Plant Pathology, SRF, \\ Agriculture University, Jodhpur, India \\ ${ }^{3}$ Department of Food Science \& Nutrition, MDS University, Ajmer, India
}

*Corresponding author

\section{A B S T R A C T}

\section{Keywords \\ Medicinal plants, Antioxidant, Eco-friendly dye, Forage, Food colorant \\ Article Info \\ Accepted: \\ 06 August 2018 \\ Available Online: \\ 10 September 2018}

This study deals with Clitoria ternatea L. which is commonly known as 'butterfly pea' and 'shankhapushpi', 'Unchan' in Thailand, 'Neel Aporajita' in Bangladesh is a climbing vine bearing purple or white flowers. It is a medicinal plant belonging to the family Fabaceae. In tropical Asia including India, the purple flowers are used for many medical purposes. The flower extract consists of antioxidant activity and protective effect. It has been commonly used as anti-stress, anti-depressant, anti-microbial, and in anti-inflammatory treatments.

\section{Introduction}

Clitoria ternatea L., commonly known as Asian pigeon wings, bluebell vine, blue pea, butterfly pea, cordofan pea and Darwin pea, is a plant species belonging to the Fabaceae family. It is a perennial plant, with elliptic, obtuse leaves. It grows as a vine or creeper, doing well in moist, neutral soil. The most striking feature about this plant is the color of its flowers, a vivid deep blue; solitary, with light yellow markings. Medicinal plants and herbs are increasingly used all over the world for health purpose. All plant parts including Leaves, seeds, bark, fruits, sprouts and stems are used medicinally. The rich biodiversity of our country has provided us plenty of raw materials, yet sustainable linkage must be developed between cultivation, collection and their use Their therapeutic, biological, pharmacological importance and safety is quite useful in making drugs and medicines.

Blue flowers contain carbohydrates, cardiac glycosides, proteins, flavonoids, flavonol glycosides, alkaloids, anthraquinone, anthocyanins, tannins, saponins, triterpenoids, phenols, volatile oils, and steroids. It has many pharmacological properties such as gastrointestinal, antiparasitic, antimicrobial, antidiabetic, and anti-inflammatory. Consumer preferences and scientific developments are changing day by day leading to an important adjustment in Indian agriculture system. 
Traditionally the root part was used for the treatment of ascetics, enlargement of the abdominal viscera, sore throat and skin diseases. Root was administered with nectar and ghee as a general tonic to kids for enhancing intellectual capacities, muscular strength. Seeds and leaves were widely used as a brain tonic and to promote cognitive skills. As an antidote for snake bite juice and flowers were used. Seeds were used in swollen joints, for urinary problems crushed seeds are taken with cold or boiled water.

\section{Act as a natural colorant in food and textiles}

In aqueous and alkaline solutions, anthocyanins exist in their blue form, the anionic quinoidal base. However, the color rapidly fades away and in most cases, the color is of low intensity due to the major proportion of the colorless hemiacetal form. Blue anthocyanin-based colors have principally been investigated in diverse flowers.

\section{Value addition in food industry}

In Southeastern Asia (Indonesia and Malaysia) and Madagascar, these flowers are often used as a food dye or dipped in batter and deepfried in form of fritters.

Beverages can be made from beautiful blue flowers in form of Herbal drink and tea, Ready to serve drinks which is full of antioxidants and phytonutrients. Flowers are used as a natural food colorant added to desserts and even in cereals such as rice, porridge to make dish appealing.

Natural dyes can produce special aesthetic qualities, which, combined with the ethical significance of a product that is environmentally friendly, gives added value to textile production as craftwork and as an industry. Color-yielding plants such as butterfly pea flowers have been used to study color extraction and can be used as dyeing material for coloring industry. Dyes obtained from natural sources have emerged as important substitutes for synthetic dyes. An increased environmental awareness of health hazards caused by synthetic dyes has led to the revival of natural dyes.

Numerous plant species are found to have an important role in the day-to-day life of the ethnic and local people. However, it is a matter of concern that the indigenous knowledge of extraction, processing, and practice of using of natural dyes has diminished to a great extent among the new generation of ethnic people due to easy availability of cheap synthetic dyes.

\section{Ornamental importance}

The attractive color of these flowers makes their way to garden and home as well as ornamental crop adding value to it. Besides so many useful properties of Butterfly Pea, it is a good source for livestock in India. It acts as multi-purpose forage legume because of its thin stem and large leaves, non- toxic nature which makes it highly palatable by livestock.

\section{Plant collection and extraction}

The fresh blue flowers were collected from the home garden, Ajmer, in June to July 2017. In the extraction process, the flowers were washed with simple (soft) water and sun-dried and dry in shade at home for two days. Fifty grams of dried flowers were added to 2 liters of boiling water and boiled till it remained quarter of the volume i.e. $500 \mathrm{ml}$. The soluble extract was filtered through nylon cloth. This extract helps to lower risk of diabetes, lowering blood sugar. Antioxidants rich drink help the body against infections and also good for heart health, for hair and skin. 

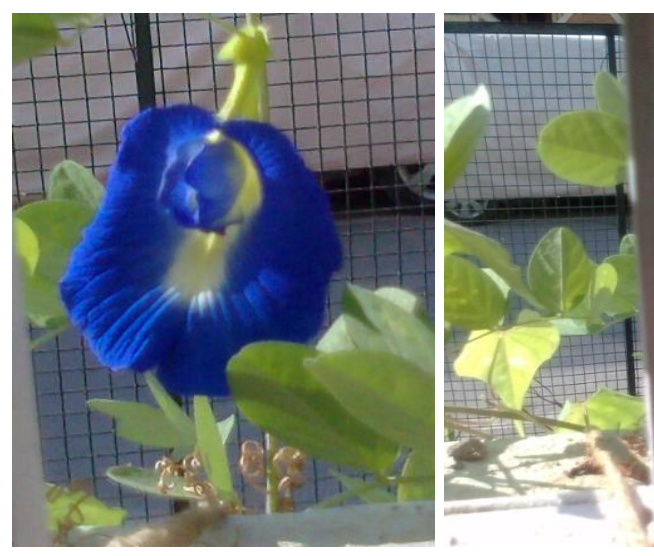

Physical properties determination

Organoleptic test consists of a determination of the color, smell, and taste of the extract.

\section{Future thrusts}

The present scenario is focused more towards the utilization of the vast diversity of natural resources of colour pigments for their use in food materials, pharmaceuticals and textiles, in place of their synthetic counterparts. This trend is aimed at safeguarding human health as well as protecting and prolonging life on earth.

An advance Eco-Friendly way of dyeing textiles with Natural Dyes. The traditional practices may have to be substituted by modern, more scientific practices in order to overcome some of the so-called disadvantages of this dye.

Need to incorporate Clitoria into farming systems, since it has a high nutritive value it will be a better solution for poor quality ruminant diets.

\section{References}

"Clitoria ternatea L". Germplasm Resources Information Network (GRIN). Agricultural
Research Service (ARS), United States Department of Agriculture (USDA). Retrieved 31 Jul 2016.

"Clitoria ternatea". Natural Resources Conservation Service PLANTS Database. USDA. Retrieved 31 Jul 2016.

Ali Esmail Al-Snafi. Pharmacological importance of Clitoria ternatea - A review. IOSR Journal of Pharmacy. March; 20166 (3): 68-83.

Alok S, Gupta N, Kumar A and Malik A. An update on Ayurvedic herb vishnukanta (Clitoria ternatea Linn.): A review. International Journal of Life Sciences and Review (IJLSR) 2015; 1(1): 19.

Anonymous. Medicinal Plants of India, Vol. I. Indian Council of Medical Research, New Delhi 1976: 260-261.

Gomez SM and Kalamani A. Butterfly pea (Clitoria ternatea): A nutritive multipurpose forage legume for the tropicsan overview, Pakistan Journal of Nutrition, 2003, 2(6): 374-379.

Kumaresan M, Palanisamy PN and Kumar PE, Application of Eco-Friendly Natural Dye Obtained from Flower of Spathodea campanulata on Silk Using Combination of Mordants, European J. Sc Research., 2011, 52 (3), 306-312.

\section{How to cite this article:}

Archna Karel, Hanwant Kumar and Bhaswati Chowdhary. 2018. Clitoria ternatea L. A Miraculous Plant. Int.J.Curr.Microbiol.App.Sci. 7(09): 672-674.

doi: https://doi.org/10.20546/ijcmas.2018.709.079 